\title{
ŚRODOWISKO PRAWNE FUNKCJONOWANIA SAMORZACDU TERYTORIALNEGO (CZY TYLKO DECENTRALIZACJA?)
}

\section{WSTĘP}

Według Jerzego Panejko, wybitnego przedstawiciela tzw. państwowej teorii samorządu terytorialnego, wszelki samorząd, nie tylko terytorialny, ale także inny (w tym zawodowy), to nic innego, jak tylko zdecentralizowana administracja państwowa ${ }^{1}$. Wspomniany autor twierdził, że samorząd to instytucja prawna „[...] powołana do załatwiania części spraw administracji państwowej w charakterze organu państwa” oraz że: „Materialnej różnicy pomiędzy administracją samorządową i rządową nie ma. Obie tworzą jedną administrację państwową"2. W konsekwencji wspomniany autor uważał, że samorząd to: „[...] oparta na przepisach ustawy zdecentralizowana administracja państwowa, wykonywana przez lokalne organy niepodległe hierarchicznie innym organom i samodzielne w granicach ustawy i ogólnego porządku prawnego"3. Zatem w tym ujęciu samorząd i administracja zdecentralizowana to określenia synonimiczne.

Zwolennicy pozytywizmu prawniczego podkreślali natomiast, że samorząd - wszelki, nie tylko terytorialny - to tylko jedna z form decentralizacji oraz że w warunkach decentralizacji funkcjonować może nie tylko samorząd, lecz także inne podmioty niemające cech samorządu ${ }^{4}$ (jak np. istniejące w latach 1997-2003 kasy chorych czy spółki wodne). W ujęciu pozytywistycznym samorządy były - podobnie jak jednostki samorządu terytorialnego oraz ich związki i stowarzyszenia - korporacjami prawa publicznego, a więc podmiotami zorganizowanymi na zasadzie członkostwa. Wspomniane kasy chorych nie miały natomiast cech samorządu, albowiem brakowało im jednej nieodłaccznej cechy samorządu, mianowicie osoby zrzeszone w kasach chorych nie miały prawa wyłaniania własnej reprezentacji. Zgodnie z treścią art. 75 ustawy z 6 lutego 1997 r. o powszechnym ubezpieczeniu zdrowotnym (Dz. U. Nr 28, poz. 153) organami regionalnych kas chorych były: 1) rada nadzorcza, 2) naczelny dyrektor, 3) naczelny lekarz regionalnej kasy oraz 4) komisja rewizyjna. Gdy

\footnotetext{
1 Panejko (1926): 97.

2 Panejko (1926): 81.

3 Panejko (1926): 97.

4 Kasznica (1947): 63-64.
} 
chodzi o piastunów kompetencji rad nadzorczych kas chorych, zgodnie z treścią art. 75, to skład osobowy tych organów kształtowany był w ten sposób, że połowę ich członków stanowili reprezentanci zgromadzenia ubezpieczonych, natomiast drugą połowę - przedstawiciele sejmików samorządowych oraz wojewodów. Zgodnie z treścią art. 76 pkt 3 i 4 tej samej ustawy rada nadzorcza powoływała i odwoływała naczelnego dyrektora oraz naczelnego lekarza kasy oraz członków komisji rewizyjnych. W takich warunkach trudno było twierdzić, że ubezpieczeni w kasach chorych mieli prawo wyłaniania własnych reprezentacji poprzez decydowanie o składzie osobowym ustawowo określonych organów kas chorych. Tymczasem samorząd (wszelki) w znaczeniu prawnym oznaczał - w ujęciu pozytywistycznym - m.in. prawo do wyłaniania własnych reprezentacji ${ }^{5}$. Pomimo to nieistniejace kasy chorych stanowiły formę decentralizacji administracji publicznej, albowiem posiadały najistotniejszą cechę decentralizacji, jaka jest ustawowo gwarantowana samodzielność w zakresie wykonywania zadań publicznych, której źródłem są ustawowe ograniczenia w zakresie możliwości dokonywania ingerencji w sprawy wspomnianych korporacji. Wspomniana ustawowo gwarantowana samodzielność w zakresie wykonywania zadań publicznych stanowi bowiem najistotniejszą cechę decentralizacji ${ }^{6}$.

\section{UWARUNKOWANIA KONSTYTUCYJNE}

Przepis art. 15 ust. 1 Konstytucji RP stanowi: „Ustrój terytorialny Rzeczypospolitej Polskiej zapewnia decentralizację władzy publicznej”. Decentralizacja ustroju terytorialnego oznacza, że podmioty władzy publicznej wykonujące zadania publiczne w terenie, a więc w poszczególnych jednostkach zasadniczego podziału terytorialnego państwa, powinny mieć zapewnioną samodzielność.

W literaturze przedmiotu prezentowany jest pogląd, zgodnie z którym gwarantowana konstytucyjne samodzielność jednostek samorządu terytorialnego jest ich prawem podmiotowym ${ }^{7}$. Jakkolwiek pogląd ten może budzić wątpliwości, ponieważ wcześniej za adresata publicznych praw podmiotowych uznawano wyłącznie tzw. jednostkę, a więc wyłącznie podmioty o takim statusie, jak człowiek (osoba fizyczna), to jednak pogląd o publicznym prawie podmiotowym do samodzielności w zakresie wykonywania zadań publicznych ${ }^{8}$ wydaje się twórczy i inspirujący.

Przepis art. 15 ust. 1 Konstytucji RP gwarantuje decentralizację ustroju terytorialnego Państwa. Decentralizacja w zakresie wykonywania władzy publicznej - jak już powiedziano - to samodzielność, a więc sytuacja, w której ingerencja w działalność podmiotu samodzielnego jest wprawdzie możliwa, ale jest ustawowo limitowana przez ograniczenie sytuacji, w których ingerencja

\footnotetext{
${ }^{5}$ Leoński (1992): 10-11.

6 Jagoda (2011): 21-23.

7 Jagoda (2011): 31.

8 Podobnie Jakimowicz (2002): 206-216.
} 
jest dopuszczalna, ograniczenie czasu ingerencji oraz ograniczenie form ingerencji. Jednakże samodzielność to nie suwerenność.

Samodzielne jednostki samorządu terytorialnego poddane zostały nadzorowi, który sprawują organy wskazane w art. 172 Konstytucji RP: Prezes Rady Ministrów, wojewodowie oraz regionalne izby obrachunkowe. Jednakże już na mocy Konstytucji RP jednostki samorządu terytorialnego, a więc: jednostki samorządu lokalnego (na dziś gminy i powiaty) ${ }^{9}$ oraz jednostki samorządu regionalnego; samorządy województw - wyposażone zostały przez ustawodawcę konstytucyjnego w kompetencje po części niezależne od ustawodawcy zwykłego. Pierwsza z tych kompetencji to kompetencja do określania - w granicach ustaw - własnego zakresu działania. Druga natomiast to kompetencja do określania - w granicach ustaw - wewnętrznego ustroju jednostek samorządu terytorialnego.

\section{ZAKRES DZIAŁANIA}

Jednostki samorządu terytorialnego, jako podmioty władzy publicznej, nie moga rozwijać swej aktywności we wszelkich dziedzinach ani w sposób dowolny decydować o kierunkach swojej aktywności. Sa bowiem powołane przez ustawodawcę zwykłego, w zgodności z art. 163 Konstytucji RP, do wykonywania wyłącznie zadań publicznych, a więc zadań zasadniczo określonych w Konstytucji RP oraz w ustawach zwykłych. Nie mogą przykładowo brać udziału w grach na giełdzie papierów wartościowych ani angażować się w podobne przedsięwzięcia powiązane z ryzykiem rynkowym. Mogą natomiast - w granicach ustaw - artykułować własne zadania w celu zaspokojenia potrzeb swych własnych mieszkańców, wychodząc - jak już była o tym mowa w odniesieniu do samorządu gminnego - poza ustawowo określony katalog zadań własnych tego samorządu. Taki jest bowiem cel i sens istnienia samorządu terytorialnego. Pierwsza zatem i istotna konstatacja jest taka, że w ramach obowiązujacej Konstytucji RP samorządy mogą rozwijać swą aktywność nie tylko na podstawie upoważnień zawartych w ustawach, lecz także poza granicami ustawowych upoważnień, jeśli tylko działalność taka ma związek z zaspokajaniem zbiorowych potrzeb wspólnot samorządowych. Zatem to nie ustawodawca zwykły, lecz prawodawca samorządowy przesądza o tym: czy i na jakich warunkach (byle w zgodzie z takimi standardami konstytucyjnymi, jak: zasada prymatu ustawy, zasada demokratycznego państwa prawnego, równości wobec prawa i równego traktowania wszystkich przez władze publiczne) przyznać albo potwierdzić określone prawo, czy też odmówić jego przyznania, czy potwierdzenia.

\footnotetext{
9 Przepis art. 1 ust. 1 ustawy z 5 czerwca 1998 r. o samorządzie powiatowym (Dz. U. 2020, poz. 920) stanowi: „Mieszkańcy powiatu tworzą z mocy prawa lokalną wspólnotę samorządową”. Zatem w obecnym stanie prawnym mamy jednostki samorządu lokalnego na szczeblu gminy oraz na szczeblu powiatu.
} 
W art. 16 ust. 1 zd. 2 Konstytucji RP przesądzone zostało, że samorząd terytorialny ma wykonywać „istotna część zadań publicznych”. Już z tego przepisu wynika, że samorząd terytorialny nie rozwija swej aktywności wyłącznie na podstawie i w zakresie określonym przez ustawodawcę zwykłego, lecz że może na podstawie art. 166 ust. 1 Konstytucji RP rozwijać swą aktywność na całym obszarze związanym z zaspokajaniem zbiorowych potrzeb wspólnoty samorządowej, jeśli tylko ustawodawca nie zastrzegł zaspokajania określonego rodzaju potrzeb na rzecz innych organów władzy publicznej.

Konkluzja czastkowa jest zatem taka, że samorząd terytorialny w aktualnych uwarunkowaniach prawnych może kreować - w granicach ustaw, ale już niekoniecznie na podstawie upoważnień zawartych w ustawach, swoje własne zadania w celu zaspokojenia potrzeb publicznych poszczególnych wspólnot samorządowych.

\section{USTRÓJ WEWNĘTRZNY JEDNOSTEK SAMORZĄDU TERYTORIALNEGO - PRAWO KOMUNALNE}

Przez pojęcie prawa komunalnego rozumie się prawo o ustroju samorządu terytorialnego ${ }^{10}$. Prawo to zawarte jest nie tylko w ustawach zwykłych, ale także w Konstytucji RP. W Polsce prawo komunalne nie jest jednak postrzegane jako „prawo o ustroju samorządu terytorialnego”. Jest natomiast postrzegane jako prawo określające zakres zadań własnych samorządu terytorialnego. Wniosek taki nasuwa treść art. 1 ustawy z 20 grudnia 1996 r. o gospodarce komunalnej (Dz. U. 2019, poz. 712), który stanowi: „Ustawa określa zasady i formy gospodarki komunalnej jednostek samorządu terytorialnego, polegające na wykonywaniu przez te jednostki zadań własnych, w celu zaspokojenia zbiorowych potrzeb wspólnoty samorządowej”.

Jedna z istotnych cech prawa komunalnego jest to, że istotna część tak rozumianych regulacji prawnych pochodzi od samych organów jednostek samorządu terytorialnego. Prawo komunalne to także prawo zawarte w statutach jednostek samorządu terytorialnego. Co ciekawe, prawo to nie jest stanowione na podstawie i w granicach upoważnień zawartych w ustawach zwykłych, lecz na podstawie upoważnienia - normy kompetencji prawodawczej - zawartego bezpośrednio Konstytucji RP. Przepisem Konstytucji PR zawierającym taka normę kompetencji prawodawczej jest art. 169 ust. 4. Przepis ten stanowi: „Ustrój wewnętrzny jednostek samorządu terytorialnego określają w granicach ustaw ich organy stanowiące". Żaden z przepisów ustaw zwykłych nie zawiera wyrażonej tak expressis verbis normy upoważniającej do regulowania ustroju wewnętrznego, i to bez potrzeby odwoływania się do upoważnień zawartych w ustawach zwykłych.

${ }^{10}$ Leoński (1992): 16-17. Nawiasem mówiąc, określenie „prawo komunalne” jest powszechnie stosowane w nauce niemieckiej dla określenia zbioru norm regulujących ustrój samorządu terytorialnego. Por. Gern (1992): 33. 
To zgoła quasi-autonomiczne upoważnienie organów stanowiących przez samego ustawodawcę konstytucyjnego do regulowania ustroju wewnętrznego tych jednostek określane bywa mianem samoistnych, w szczególności w odniesieniu do statutów ${ }^{11}$. Nie wydaje się jednak, by określenie „akty samoistne” odnoszone do aktów wydawanych na podstawie normy kompetencji prawodawczej zawartej bezpośrednio w Konstytucji RP mogło budzić zastrzeżenia.

\section{ZADANIA WLASNE}

Samorząd terytorialny powołany został do wykonywania istotnej części zadań publicznych. Przy tym - jak już powiedziano - nie wszystkie z tych zadań, które mają wykonywać jednostki samorządu terytorialnego, zostały wyartykułowane przez ustawodawcę zwykłego. Część z nich jest wykonywana przez reprezentacje i jednostki organizacyjne wspólnot samorządowych na tej zasadzie, że reprezentacje te dokonały swego rodzaju odkrycia potrzeb wspólnot samorządowych i ustaliły, że potrzeby te - jako potrzeby zbiorowe - wymagają zaspokojenia, zgodnie z misją samorządu terytorialnego, wyartykułowana w art. 166 ust. 1 Konstytucji RP.

Jednostki samorządu terytorialnego, a także kreowane przez nie podmioty, jak związki czy stowarzyszenia jednostek samorządu terytorialnego, nie mają i nie mogą mieć innych zadań, jak tylko publiczne. Jednakże - jak już wspomniano - nie wszystkie spośród tych zadań zostały wyartykułowane w formie i drodze ustawowej. Jest tak dlatego, że w świetle art. 166 ust. 1 Konstytucji RP oraz w świetle art. 7 ust. 1 zd. 1 ustawy z 8 marca 1990 r. o samorządzie gminnym nie ma ustawowo określonego i ustawowo zamkniętego katalogu zadań publicznych, związanego z zaspokajaniem potrzeb publicznych. Oznacza to, że bezpośrednio na podstawie upoważnienia zawartego w art. 166 ust. 1 Konstytucji RP jednostki samorządu terytorialnego, a więc wspólnoty lokalne oraz regionalne, moga same - bez potrzeby upoważnienia zawartego w ustawach zwykłych: a) artykułować potrzeby wspólnot samorządowych oraz b) decydować o tym, w jaki sposób potrzeby te będą zaspokajane. Zgodnie bowiem z treścią art. 166 ust. 2 Konstytucji RP, który stanowi: „Jeżeli wynika to z uzasadnionych potrzeb państwa, ustawa może zlecić jednostkom samorządu terytorialnego wykonywanie innych zadań publicznych. Ustawa określa tryb przekazywania i sposób wykonywania zadań zleconych”, ustawodawca zwykły nie powinien narzucać jednostkom samorządu terytorialnego sposobów wykonywania zadań własnych. W istocie więc reprezentacje jednostek samorzadu terytorialnego zostały konstytucyjnie umocowane do tego, by dokonywać konkretyzacji tego, co mieści się w zakresie zaspokajania zbiorowych potrzeb wspólnot samorządowych wspólnot samorządowych oraz w jaki sposób powinno się dokonywać zaspokajanie tych potrzeb. 
Rzecz oczywista nie oznacza to żadnej dowolności. Gmina (powiat czy województwo samorządowe) nie może uczestniczyć w grze na rynku papierów wartościowych. Nie może też deponować wolnych środków finansowych w bankach komercyjnych, nawet gdyby wiązały się z tym lukratywne zyski. Jednostki samorządu terytorialnego mogą wprawdzie zawierać różnorakie umowy z innymi podmiotami, także prywatnymi, ale wyłącznie pod takim warunkiem, że zawieranie tych umów będzie pozostawać w związku z wykonywaniem zadań własnych spoczywających na tych jednostkach oraz pod warunkiem, że sposób zaspokajania tych potrzeb będzie czynić zadość zasadom i wartościom wpisanym do treści Konstytucji RP.

\section{USTRÓJ WEWNĘTRZNY}

Ustrój wewnętrzny jednostek samorządu terytorialnego również nie jest określany na podstawie upoważnień zawartych w ustawach zwykłych. Zgodnie z treścia art. 169 ust. 4 Konstytucji RP: „Ustrój wewnętrzny jednostek samorządu terytorialnego określają $\mathrm{w}$ granicach ustaw ich organy stanowiace”. I w tym przypadku uwagę zwraca, że określanie ustroju wewnętrznego nie wymaga upoważnień zawartych w ustawach zwykłych, lecz że odbywać się ono może bezpośrednio na podstawie upoważnienia zawartego w samej Konstytucji RP.

Takie uregulowanie problematyki ustroju wewnętrznego jednostek samorządu terytorialnego ma swe daleko idące konsekwencje. Przede wszystkim oznacza to upoważnienie do dostosowywania własnych struktur wewnętrznych do zadań, których realizacja ma prowadzić do zaspokajania potrzeb danej wspólnoty samorządowej. Upoważnienie to może obejmować kreowanie struktur wewnętrznego ustroju jednostek samorządu terytorialnego, które nie zostały przewidziane ani konstytucyjnie, ani w drodze ustaw zwykłych. Nierychło jednak zostały one w sposób właściwy odkodowane przez judykaturę ${ }^{12}$. Przez wiele lat od momentu wejścia w życie ustawy z 8 marca 1990 r. o samorządzie terytorialnym, także po wejściu w życie Konstytucji RP z jej art. 169 ust. 4, pokutował w judykaturze sądowoadministracyjnej pogląd, wedle którego organy stanowiące jednostek samorządu terytorialnego nie były upoważnione do kreowania żadnych innych struktur wewnętrznych niż te, które zostały przewidziane przez ustawodawcę zwykłego ${ }^{13}$. Szczęśliwym biegiem zdarzeń zapatrywanie takie ustapiło zdecydowanie bardziej zasadnemu poglądowi, uwzględniającemu normatywną treść art. 169 ust. 4 Konstytucji RP, idącemu ku wykładni prokonstytucyjnej, a jednocześnie akcentującemu daleko idącą samodzielność w zakresie kreowania wewnętrznego ustroju jednostek samorządu terytorialnego. W linię tę wpisuja się takie orzeczenia, jak wyrok II SA/Ol 196/13 WSA w Olsztynie z 14 maja 2013 z aprobująca glosą Huberta

12 Szerzej na ten temat: Sypniewski, Szewczyk (2018): 1-5.

13 Sypniewski, Szewczyk (2018): 4. 
Izdebskiego ${ }^{14}$. Powyższy kierunek orzeczniczy został w pełni zaakceptowany przez NSA w wyroku II OSK 1887/13 z 21 listopada 2013 r. W uzasadnieniu tego wyroku wzbogaceniu uległa argumentacja przemawiajaca za zmianą dotychczasowej linii orzeczniczej przez odwołanie się do wiążących Polskę unormowań międzynarodowych, to jest art. 15 (dawniej art. 255) Traktatu o funkcjonowaniu Unii Europejskiej (wersja skonsolidowana Dz. Urz. UE C 85/54 z 30 marca 2010 r.), art. 10 Traktatu Unii Europejskiej (wersja skonsolidowana Dz. Urz. UE C 326/15 z 26 października 2012 r.) i preambułę oraz art. 3 Europejskiej karty samorządu lokalnego, sporządzonej w Strasburgu dnia 15 października 1985 r. (Dz. U. 1994, poz. 607). Antycypacji, a nawet rozwinięcia tego stanowiska dokonano w doktrynie ${ }^{15}$.

\section{CZY TYLKO DECENTRALIZACJA?}

W powyżej naszkicowanych warunkach powstaje zasadnicze pytanie: czy ramy prawne polskiego samorządu terytorialnego zamykają ten samorząd wyłącznie w warunkach decentralizacji, czy też samorząd polski ma większe spektrum wolności, sięgające - być może - do autonomii terytorialnej? Przypomnieć zatem wypadnie, że tym, co różni układ decentralizacji od układu autonomii, jest dekoncentracja władzy ustawodawczej w zakresie ustawodawstwa zwykłego. Dekoncentracja władzy ustawodawczej oznacza, że w danym systemie prawnym funkcjonować może więcej niż jeden organ wyposażony w kompetencje do stanowienia prawa rangą równego ustawie zwykłej.

W warunkach polskich nie ma wątpliwości co do tego, że - wyjąwszy stany nadzwyczajne - ustawodawca jest tylko jeden oraz że jest nim Sejm RP. Taka konstatacje wydaje się wspierać art. 3 Konstytucji RP, zgodnie z którym Rzeczpospolita jest państwem jednolitym. Czy można zatem twierdzić, że „ustawodawcami” - w sensie posiadania upoważnień do stanowienia prawa na podstawie upoważnienia zawartego bezpośrednio w Konstytucji - są w Polsce także organy stanowiące jednostek samorządu terytorialnego, a w szczególności rady gmin?

Wydaje się, że na to z pozoru obrazoburcze pytanie można odpowiedzieć twierdząco. Skoro bowiem organy stanowiące jednostek samorządu terytorialnego zostały przez ustawodawcę konstytucyjnego upoważnione do ustanawiania, bez zważania na ustawowe upoważnienia oraz bez zakreślenia przez ustawodawcę zwykłego granic ustawowych upoważnień, do kreowania swych własnych zadań oraz swych struktur wewnętrznych, z zastrzeżeniem jedynie zawartym w Konstytucji RP, że mają to być zadania publiczne, polegające na zaspokajaniu potrzeb zbiorowych wspólnot terytorialnych - gdy chodzi o zakres aktywności (art. 166 ust. 1 Konstytucji RP) - oraz że struktury wewnętrzne muszą respektować podstawowe założenia ustrojowe wyrażone w art. 169

14 Izdebski (2014): 165-167.

15 Dolnicki (2016); Kisiel (2010): 72; Szewczyk (2018): 240-243. 
ust. 1-3 Konstytucji RP, oraz w ustawach określających ustrój poszczególnych rodzajów jednostek samorządu terytorialnego, to można - jak się wydaje - powiedzieć, że konstytucyjne umocowanie jednostek samorządu terytorialnego wykracza poza to, co zwykło się traktować w tradycji polskiej nauki prawa administracyjnego jako decentralizację władzy publicznej. Nie jest to bowiem jedynie samodzielność w zakresie stosowania prawa. Jest to samodzielność obejmująca kreowanie, a więc stanowienie prawa bez upoważnień zawartych w ustawach zwykłych.

Rzecz oczywista, prawo stanowione przez organy stanowiace jednostek samorządu terytorialnego nie ma rangi ustawy. Ustawodawca zwykły może w każdej chwili zniweczyć regulację prawną ustanowioną przez samorząd terytorialny. Nadto ustawodawca konstytucyjny nie ustanowił dla ustawodawcy zwykłego jakichkolwiek barier, poza które nie może on wkroczyć ze swa regulacją w zakresie zadań własnych oraz struktur wewnętrznych. Wymownym przykładem jest w tym względzie ustawa z 11 stycznia 2018 r. o zmianie niektórych ustaw w celu zwiększenia udziału obywateli w procesie wybierania, funkcjonowania i kontrolowania niektórych organów publicznych (Dz. U. 2018, poz. 130). Moca tej ustawy ustawodawca polski wdrożył odgórnie rozwiązania, które w innych krajach Europy Zachodniej wdrażane były i sa „oddolnie", a które u naszych zachodnich sąsiadów określane są mianem gminy obywatelskiej (Bürgerkommune) ${ }^{16} \mathrm{z}$ takimi charakterystycznymi instytucjami, jak obywatelska inicjatywa uchwałodawcza, budżet obywatelski czy raport o stanie gminy (powiatu, samorządu województwa).

Można zatem powiedzieć, że polskiemu systemowi prawnemu znane sa rozwiązania wykraczające poza tradycyjnie rozumianą decentralizację. Samodzielność, jaką cieszy się polski samorząd terytorialny, wykracza poza stosowanie prawa i obejmuje stanowienie aktów normatywnych bezpośrednio na podstawie upoważnień zawartych w Konstytucji RP. W tej sytuacji nasuwa się pytanie: czego brakuje polskiemu samorządowi, by mówić, iż funkcjonuje on, podobnie jak w Republice Włoskiej czy w Królestwie Hiszpanii, w warunkach autonomii? Trzeba bowiem skonstatować, że decentralizacja nie jest jedynym środowiskiem prawnym, w którym może funkcjonować samorząd terytorialny. Można twierdzić, że środowisko tradycyjnie rozumianej decentralizacji to swego rodzaju minimum konieczne do funkcjonowania samorządu, warunek konieczny. Samorząd terytorialny, jak dowodzą tego przykłady zaczerpnięte z unormowań prawnych obowiązujących we Włoszech czy Hiszpanii, a także przykład z czasów II Rzeczpospolitej Polskiej (w odniesieniu do byłego województwa śląskiego), może z powodzeniem funkcjonować także w warunkach autonomii, a nawet - jak w przypadku Republiki Federalnej Niemiec, Republiki Austrii czy Konfederacji Szwajcarskiej - w warunkach państw federalnych. Samorząd nie może natomiast funkcjonować w warunkach braku ustawowo gwarantowanej jednostkom tego samorządu samodzielności w zakresie przynajmniej stosowania prawa. I ustawowo gwarantowana samodzielność w zakresie stosowania prawa stanowi absolutne minimum, bez którego samo-

${ }^{16}$ Bauer (2017): 15 n.; podobnie Lübking (2017): 33 n. 
rząd terytorialny obejść się nie może. Autonomia jest natomiast zasadą dotyczącą organizacji wykonywania zadań publicznych, która dla funkcjonowania samorządu terytorialnego nieodzowna nie jest.

\section{SAMORZĄD - DECENTRALIZACJA - AUTONOMIA}

W interesującej monografii Sadowa ochrona samodzielności jednostek samorzqdu terytorialnego jej autorka, Joanna Jagoda, zamieściła fragment, który zatytułowała następująco: „Samorząd a autonomia” i skonstatowała, że: „Pojęciem związanym z samorządem terytorialnym jest autonomia, który to termin jest używany w literaturze przedmiotu zarówno jako pojęcie o odrębnym znaczeniu, jak i stosowany zamiennie z określeniem "samorząd terytorialny«. Czynnikiem, który pozwala rozróżnić te dwie instytucje prawne, jest m.in. przypisywany im zakres samodzielności. Na problem korelacji samorządu i autonomii zwracano uwagę już w literaturze okresu dwudziestolecia międzywojennego, kiedy to autonomię uznawano za pojęcie niejako organicznie związane z samorządem terytorialnym. Jej istotą było, jak podnosiło wielu autorów [...] uprawnienie jednostki publicznoprawnej do wydawania obowiązujących norm prawnych [...] choć niektórzy stwierdzali, że autonomia jest także przekazanie takich uprawnień »części państwa«, zatem części jego terytorium"17.

Nie jest to na szczęście jedyne zapatrywanie na autonomię, które znalazło swój wyraz w nauce prawa z czasów II Rzeczypospolitej. Bardziej miarodajne wydaje się pochodzące również z czasów II Rzeczypospolitej stanowisko Wacława Makowskiego, który twierdził, że: „Autonomia może być terytorialna, obejmować jakąś prowincję, kraj; rozmaite nazwy bywają nadawane terytoriom wyposażonym $\mathrm{w}$ autonomię; - może także z autonomii korzystać zrzeszenie częściowe, nie związane z terytorium, ale oparte na łączniku celowym. Tak np. kościół może mieć organizację autonomiczną w łonie organizacji państwowej. Pojęcie autonomii obejmuje rządzenie się własnymi prawami, odrębnymi od ogólnych praw państwa, a więc także i możność stanowienia praw dla swojego związku autonomicznego. Autonomia jednak musi być objęta przez ogólny porządek prawny państwa, musi więc mu podlegać i mieścić się w jego granicach, nie może naruszać jego zasad"18. Takie ujęcie istoty autonomii charakteryzowało ją o wiele bardziej trafnie.

Co więcej, przykłady rozwiązań prawnych obowiązujących w prawie Republiki Włoskiej oraz w prawie Królestwa Hiszpanii wskazują na to, że na zasadzie autonomii terytorialnej (lokalnej lub regionalnej) moga funkcjonować także te państwa, które przyjmują zasadę ustrojową unitaryzmu. W art. 5 zd. 1 Konstytucji Republiki Włoskiej (Costituzione della Republica Italiana) z 27 grudnia 1947 r. została zadeklarowana zasada unitaryzmu. Wspomnia-

\footnotetext{
17 Jagoda (2011): 37.

18 Makowski (1939): 187.
} 
ny przepis stanowi: „Republika jest jednolita i niepodzielna”19. Jednocześnie jeszcze w tym samym przepisie, w dalszym jego fragmencie, napisane jest, że ta jednolita i niepodzielna Republika: „uznaje i wspiera autonomie lokalne"20. W dalszym fragmencie tego samego przepisu napisane jest, że Republika Włoska: „urzeczywistnia w działalności służb podległych państwu najszerszą decentralizację administracyjna; dostosowuje zasady i system swojego ustawodawstwa do potrzeb autonomii i decentralizacji” ${ }^{21}$. Podobne treści znaleźć można w art. 2 Konstytucji Królestwa Hiszpanii (Constitución Española) z 27 grudnia 1978 r. Przepis ten stanowi: „Konstytucja opiera się na nierozerwalnej jedności Narodu hiszpańskiego, wspólnej i niepodzielnej ojczyzny wszystkich Hiszpanów, a także uznaje i zapewnia prawo do autonomii stanowiących go narodowości i regionów oraz solidarność między wszystkimi”22. Jak więc widać, autonomia nie wyklucza jednolitości państwa i nie musi łączyć się z przekazaniem komukolwiek części terytorium. Można, a wręcz należy nawet powiedzieć, że autonomia nie obejmuje uprawnienia do decydowania mieszkańców części autonomicznej o jej przynależności państwowej. Dlatego zarówno próby oderwania się Katalonii od Królestwa Hiszpanii, jak i aneksja Krymu przez Rosję zostały potraktowane jako zamierzenia niedające się pogodzić z międzynarodowym porządkiem prawnym.

Podkreślenia wymaga jeszcze jedna kwestia: otóż samo przeciwstawianie samorządu autonomii, jak to uczyniła Jagoda w tytule jednego z punktów w rozdziale I wspomnianej monografii „Samorząd a autonomia”, wydaje się niewłaściwe. Samorząd bowiem to rodzaj podmiotu administracji publicznej. Autonomia natomiast to zasada organizacji władzy publicznej w terenie. Sa to więc odrębne kategorialnie pojęcia. Autonomię można - jak się wydaje - porównywać z decentralizacja, a nie z samorządem. Autonomia bowiem, podobnie jak decentralizacja, stanowi zasadę organizacji władzy publicznej. Tyle tylko, że o ile autonomia obejmuje samodzielność nie tylko w zakresie wykonywania prawa, ale i stanowienia prawa rangą niższego niż ustawa, co prowadzi do dekoncentracji władzy ustawodawczej, o tyle decentralizacja obejmuje jedynie samodzielność w zakresie stosowania prawa oraz stanowienia prawa, jednakże rangą niższego niż ustawy zwykłe. Dlatego trudno jest podzielić stanowisko wspomnianej autorki, gdy twierdzi ona, że: „Samorząd

19 W oryginale: „La Republica, una e indivibile”.

${ }^{20}$ W oryginale: „riconosce e promuove le autonomie locali”; w tłumaczeniu Z. Witkowskiego: „uznaje i wspiera samorząd lokalny”, podaję za: Konstytucja Włoch, Costituzione della Republica Italiana, tłum. Z. Witkowski, <biblioteka.sejm.gov.pl>.

${ }^{21}$ W oryginale: „La Republica [...] attua nei servisi che dipendono dallo Stato il piu ampio decentralmento amministrativo; adegua i principi ed i metodi della sua legislazione alle esigenza dell'autonomia e del decentralmento”; w tłumaczeniu Z. Witkowskiego: „Republika [...] urzeczywistnia w działalności służb podlegających państwu najszerszą decentralizację administracji; dostosowuje zasady i system swojego ustawodawstwa do wymagań samorządu i decentralizacji”. Znamienne jest, że Witkowski w swoim tłumaczeniu zastapił słowo „autonomia” słowem „samorząd”. Używa jednak słowa „autonomia” w tłumaczeniu przepisów art. 114, 116 i 117 Konstytucji Republiki Włoskiej.

${ }^{22}$ Podaję za: Konstytucja Hiszpanii, Constitución Española, tłum. T. Mołdawa, <biblioteka. sejm.gov.pl>. 
[...] nie jest i nie może być organizacją autonomiczna”. Stanowisku takiemu przeczy przytoczone wyżej prawodawstwo Republiki Włoskiej oraz Królestwa Hiszpanii. Stanowisku temu przeczą także rozwiązania prawne o charakterze historycznym, które obowiazywały w czasach II Rzeczypospolitej na terenie województwa śląskiego.

\section{KONKLUZJA}

Konkludując, wypada stwierdzić, że samorząd terytorialny może współcześnie funkcjonować zarówno w warunkach jedynie decentralizacji, jak i równie dobrze może też funkcjonować w warunkach autonomii, jak w Republice Włoskiej czy w Królestwie Hiszpanii. Może wreszcie funkcjonować w warunkach quasi-autonomii z upoważnieniem na mocy Konstytucji RP do określania $\mathrm{w}$ granicach ustaw, a nie na podstawie upoważnień zawartych w ustawach, własnych zadań oraz własnych struktur wewnętrznych, jak ma to miejsce w Polsce.

Określenie „quasi-autonomia” ma stanowić sugestywny wyraz tego, że nie jest to rozwiązanie, w którym wskazane wyżej sfery określania zadań własnych oraz określania swych struktur wewnętrznych nie zostały objęte konstytucyjnymi gwarancjami nieingerencji ze strony ustawodawcy zwykłego.

Marek Szewczyk

Uniwersytet im. Adama Mickiewicza w Poznaniu

marek@szewczyk.poznan.pl

https://orcid.org/0000-0001-8222-7898

Bauer, H., Hajasch, L. (2017). Vom passiven Untertanen, über den Wutbürger zum aktiven Citoyen in der Bürgerkommune, [w:] H. Bauer, Ch. Büchner, L. Hajasch (Hrsg.), Partizipation in der Bürgerkommune. Potsdam: 15-32.

Dolnicki, B. (2016). Samorząd terytorialny. Wydanie 6. Warszawa.

Gern, A. (1992). Kommunalrecht für Baden-Wirtemberg. Baden-Baden.

Izdebski, H. (2014). Glosa do wyroku WSA w Olsztynie z 14 maja 2013 r., II S.A./Ol 196/13. Samorzą Terytorialny 24(1/2).

Jagoda, J. (2011). Sądowa ochrona samodzielności jednostek samorządu terytorialnego. Warszawa.

Jakimowicz, W. (2002). Publiczne prawa podmiotowe. Warszawa.

Kasznica, S. (1947). Polskie prawo administracyjne. Poznań.

Kisiel. W. (2010) [w:] P. Chmielnicki (red.), Ustawa o samorządzie gminnym. Komentarz. Warszawa.

Leoński, Z. (1992). Prawo administracyjne. Warszawa.

Lübking U. (2017). Rechtliche Grundlagender Bürgerbeteiligunge, [w:] H. Bauer, Ch. Büchner, L. Hajasch (Hrsg.), Partizipation in der Bürgerkommune. Potsdam: 33-44.

Makowski, W. (1939). Nauka o państwie. Część 1: Teoria państwa. Warszawa.

Panejko, J. (1926). Geneza i podstawy samorządu europejskiego. Paryż 1926.

Sypniewski, Z., Szewczyk, M. (2018). Wzorcowy statut gminy. Poznań.

Szewczyk, M. (2018). Quasi-autonomia statutowa jednostek samorządu terytorialnego, [w:] K. Małysa-Sulińska, M. Stec (red.), Konstytucyjne umocowanie samorządu terytorialnego. Warszawa. 


\section{THE LEGAL ENVIRONMENT FOR THE FUNCTIONING OF LOCAL SELF-GOVERNMENT (OR JUST DECENTRALIZATION?)}

\section{Sum mary}

The article presents the legal environment in which local self-governments may operate. The author seeks to demonstrate that such an environment can be one characteristic for the decentralization of public administration, understood as independence in the field of law application, without simultaneous independence in the field of law-making that is equal to the rank of an ordinary act. However, in the author's opinion, a local self-government may also function autonomously, which involves independence not only in the application of the law, but also in adopting acts with the rank of an ordinary act, as was the case in the Silesian Voivodeship in the times of the Second Polish Republic, and as found today in the Italian Republic and the Kingdom of Spain. Finally, local self-government can also function under conditions of quasi-autonomy. The author suggests that in this case individual units of local self-government have been directly equipped by the constitutional legislator with the right to articulate their own tasks - within the limits specified in the provisions of the Constitution of the Republic of Poland - and to define their internal structures, without the need to appoint - as a legal basis - authorizations included in ordinary acts, and without constitutional guarantees of non-interference in these two spheres by the ordinary legislator.

Keywords: decentralization; autonomy; local self-government; independence 